\title{
HISTIOCYTIC BONE AND JOINT DISEASE
}

\author{
BY \\ B. M. ANSELL AND E. G. L. BYWATERS \\ From the Postgraduate Medical School of London and Hammersmith Hospital, London
}

Joint changes associated with histiocyte or foam cell infiltration of bone are of various kinds and often only with some difficulty differentiated from one another. Thus, in rheumatoid arthritis, any long-standing effusion or nodule will contain cholesterol, and we have sometimes seen the flat crystals of cholesterol shimmering in aspirated synovial fluid. A case of this nature was recently described by Golden and Richards (1953) where the cholesterol-containing synovial effusion of a Baker's cyst had entered the bone and replaced most of the marrow; the case described by Fletcher (1946) falls into this class.

Secondly, hypercholesterolaemia may coincidentally supervene in a patient with rheumatoid arthritis; a patient described by Layani (1939) and also fully described by Vishnevsky (1939) obviously falls into this category, although it was described as le rhumatisme chronique déformant xanthomateux and was thought to represent a new form of chronic rheumatism.

Thirdly, primary familial hypercholesterolaemia is often accompanied by osseous defects. These erosions are frequently para-articular, as was illustrated by Merrill (1920) and by March, Gilbert, and Kain (1957). As the latter authors remark, there is a "tendency not to involve the articular margin of joints". However Gaál (1933) illustrated such defects in a man of 38 years with increased blood cholesterol (650 mg. per cent.) and with pain in various joints for 2 years accompanied by an effusion, thought to be tuberculous and hence necessitating amputation. The defects illustrated in the thumb, digits, and wrist include not only paraarticular erosions on the medial side of the distal radius, etc., but also erosions affecting the articular surfaces of the digital bones.

Fourthly, idiopathic hyperlipaemia with or without pancreatitis does not seem to lead to bone defects (Hopgood, 1948; Lever, Smith, and Hurley, 1954; Corazza and Myerson, 1957), although Harslöf (1948) has recorded a man with milky serum and yellow nodules developing rheumatoid arthritis.

Fifthly, excellent descriptions have recently been published (Warin, Evans, Hewitt, Taylor, Price, and Middlemiss, 1957; Johnson and Tilden, 1957) of a deforming erosive type of rheumatism with absorption of articular bone ends associated with an infiltration of lipoprotein-containing cells but with no lipoid deposition or hypercholesterolaemia: twelve previously published cases of "reticulohistiocytosis" are cited most of them with joint symptoms.

Finally, the bone changes of another metabolic disorder-Gaucher's disease-may simulate osteomyelitis and by collapse of subchondral bone lead to degenerative joint changes and severe osteoarthritic symptoms.

We have not, however, seen a reference to joint changes observed radiologically in biliary cirrhosis with secondary hypercholesterolaemia (MacMahon, 1948; Movitt, 1956); the object of the present study is to record three such cases and to compare these findings with a series of in-patients with other "storage diseases" such as are briefly referred to above.

\section{Case Reports}

Case 1, a female aged 32 years, first developed jaundice in 1951 followed by itching and one year later by nodules in the skin. Laparotomy revealed normal bile passages, so that the obstruction was considered to be intrahepatic. When seen in 1953 she was deeply jaundiced and showed many cutaneous xanthomata but no joint or bone abnormalities.

Laboratory Investigations.-Erythrocyte sedimentation rate $115 \mathrm{~mm}$./ $\mathrm{hr}$ (Westergren); plasma cholesterol 622 mg. per cent.; serum bilirubin $13.5 \mathrm{mg}$. per cent.; alkaline phosphatase 82 King Armstrong units; serum proteins: albumin $4.0 \mathrm{~g}$. per cent., globulin $3 \mathrm{~g}$. per cent.

$X$-Ray Examination.-The lumbar spine, hands, and skull showed mild osteoporosis.

Calcium balance and bone biopsy confirmed a state of osteoporosis.

Therapy.-She was treated with calcium lactate and extra vitamins.

Progress.-By 1956, the serum bilirubin was unchanged $(9 \cdot 5 \mathrm{~g}$. per cent.) and the xanthomata were disappearing, but the cholesterol was $1,500 \mathrm{mg}$. per cent. Now, in addition to osteoporosis, erosions were noted on the 


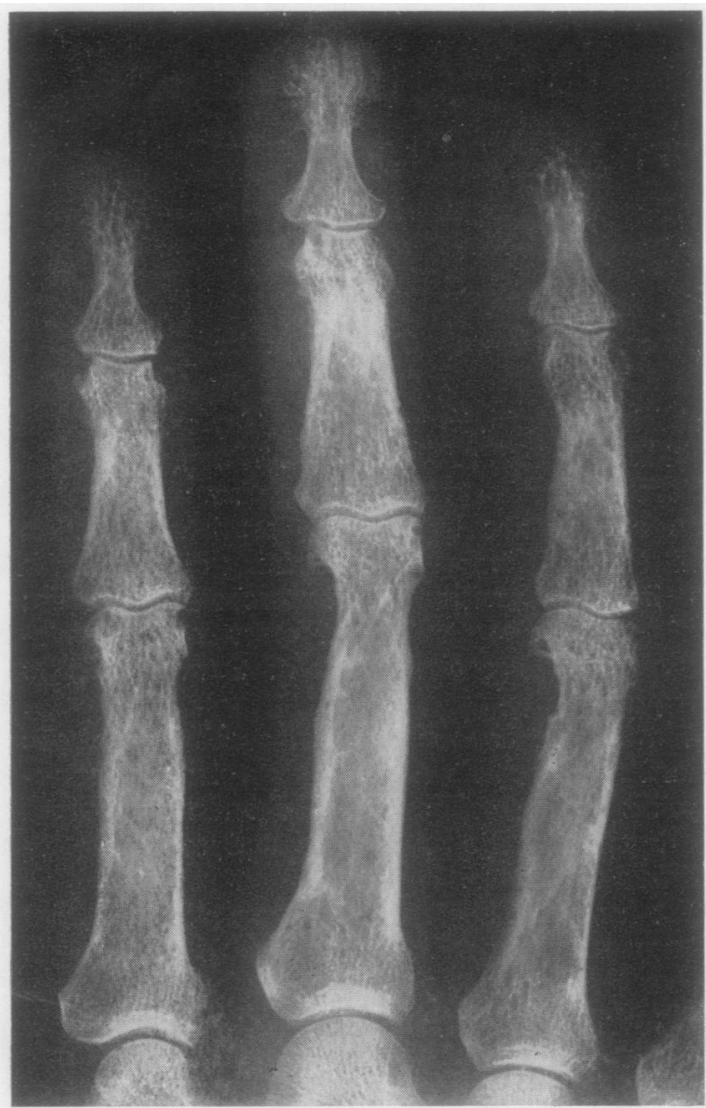

Fig. 1.-Case 1, $x$-ray of 2 nd, 3rd, and 4th fingers of left hand, showing articulation of bone and absorption in juxta-articular and subchondral areas of terminal phalanges 2 and 3 and proximal interphalangeal joints 2,3 , and 4 .

hand $x$-rays. By July, 1957, the cholesterol was 3,000 mg. per cent. and the bone changes were more marked. These consisted of osteoporosis and coarse reticulation with erosions proximal to the ends (Fig. 1), which were particularly well seen in the three middle digits of both hands. There was also erosions of bone on the heads of the middle phalanges on both the radial and ulnar sides of the joints. This had progressed in both middle and proximal phalanges to destroy part of the articular surfaces. In addition there was now widespread infiltration in the bones of the forearm (Fig. 2).

Comment.-Despite these advanced changes, there were no complaints referable to the bones or joints.

Case 2, a female aged 46 years, was first seen in February, 1957, complaining of pain in the ankle on movement and some swelling of the ankles. She gave a history of jaundice commencing in 1950, which had been persistent since then and associated with pruritus. In 1955 , she had complained of pain in the right hip, but at this time there was no limitation of movement. The pain persisted and movement deteriorated, and both of

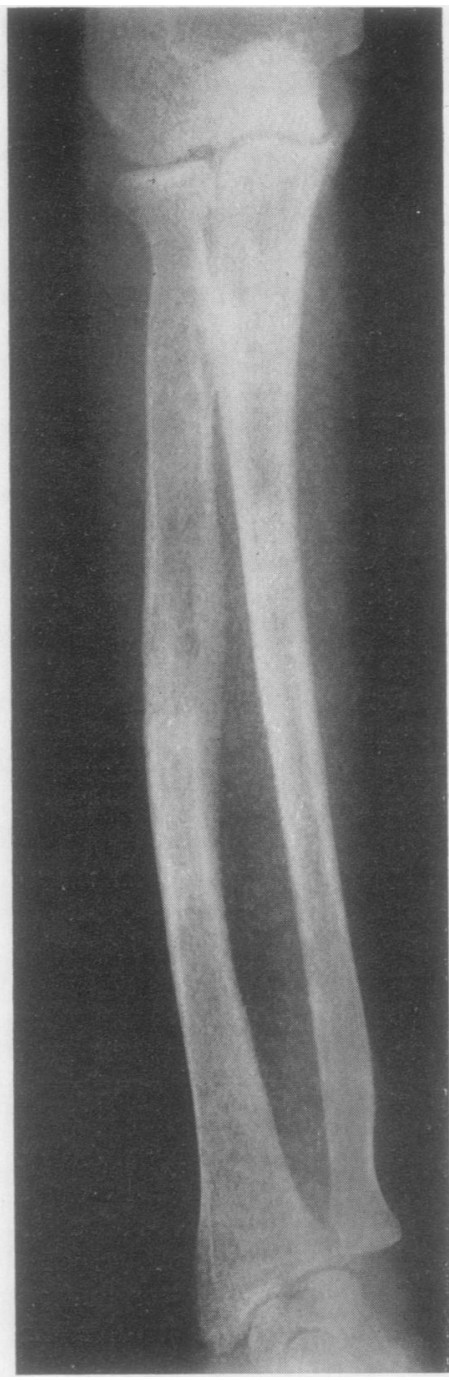

Fig. 2.-Case 1, $x$-ray of forearm, showing bone pseudo-cysts

these were aggravated by a fall in May, 1956, so that by December, 1956, she was only too willing to take to a caliper. For the past year she had been on a high 윽 calcium diet.

Examination.-She was grossly jaundiced, the liver and spleen were easily palpable, and there was clubbing $N$ of the nails. All the hand joints including the terminal or interphalangeals were completely normal, but there was $N$ marked limitation and pain on movement of the right N hip. There were now no tendon nodules or cutaneous $\omega$ lesions to be seen, although they had been present up to one year previously.

Laboratory Investigations.-Serum bilirubin $24 \mathrm{mg}$. per cent.; plasma cholesterol $420 \mathrm{mg}$. per cent.; alkaline ? phosphatase 16 King Armstrong units; erythrocyte 
sedimentation rate $48 \mathrm{~mm}$./hr (Westergren). C-reactive protein present; serum proteins: albumin $2.9 \mathrm{~g}$. per cent.; globulin 2.9 g. per cent.; calcium $4.8 \mathrm{mEq} . / 1$.; phosphate $2.9 \mathrm{mEq} . / 1$.

Liver biopsy showed biliary cirrhosis.

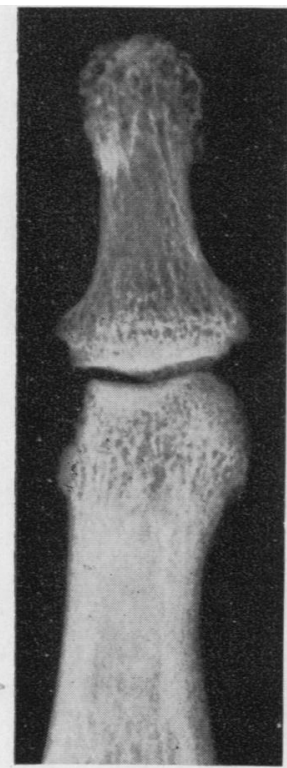

1953

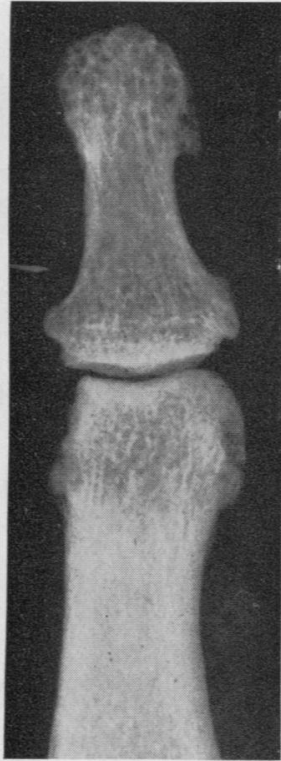

1955

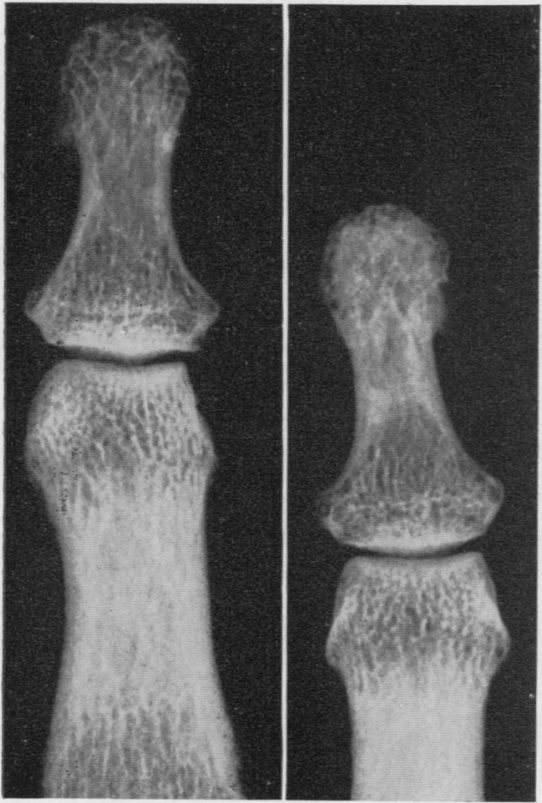

1953
$X$ rays of the hands showed bone erosions affecting the proximal phalangeal heads and adjacent joint surfaces, starting in 1945 and progressing inexorably.

Progress.-The series of $x$ rays reproduced in Fig. 3 show the changes in the third right terminal phalanx

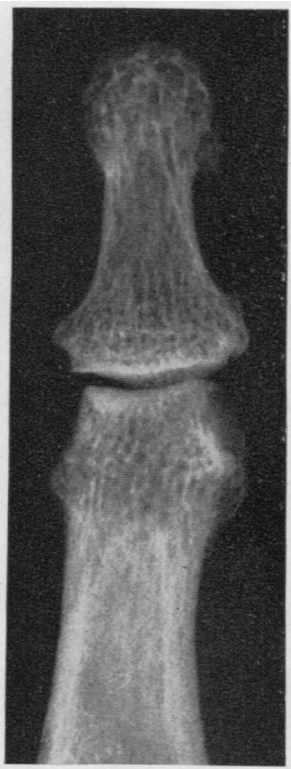

(a)

1956

1957

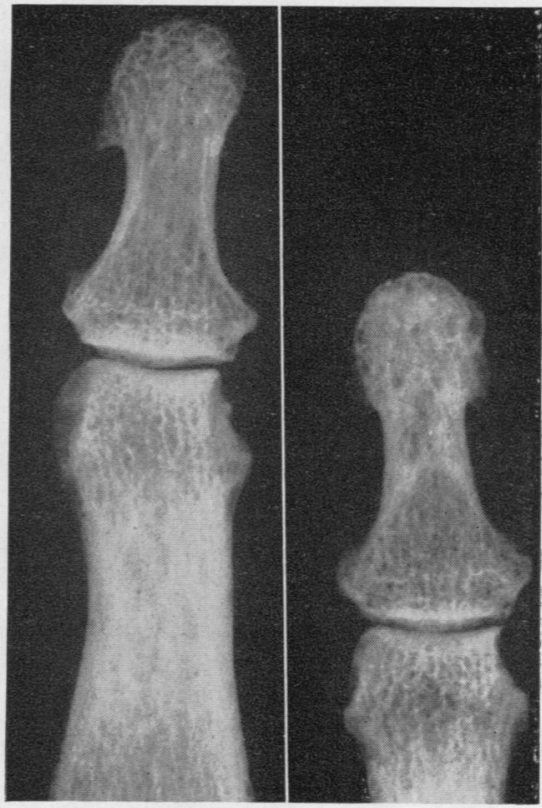

1955

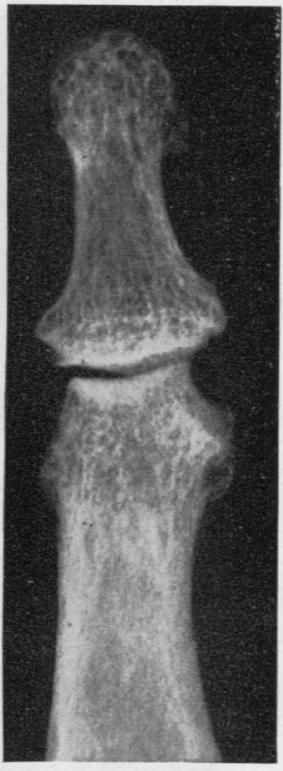

(b)

in subchondral areas, leading to apparent erosion. $\times 2$.

(b) 2nd and 3rd terminal interphalangeal joints of right hand in 1953 and $1955 . \times 2$

Fig. 3.-Case 2 (a) $x$-ray of 3rd terminal interphalangeal joint of left hand in 1953, 1955, 1956, and 1957, showing rarefaction of bone 

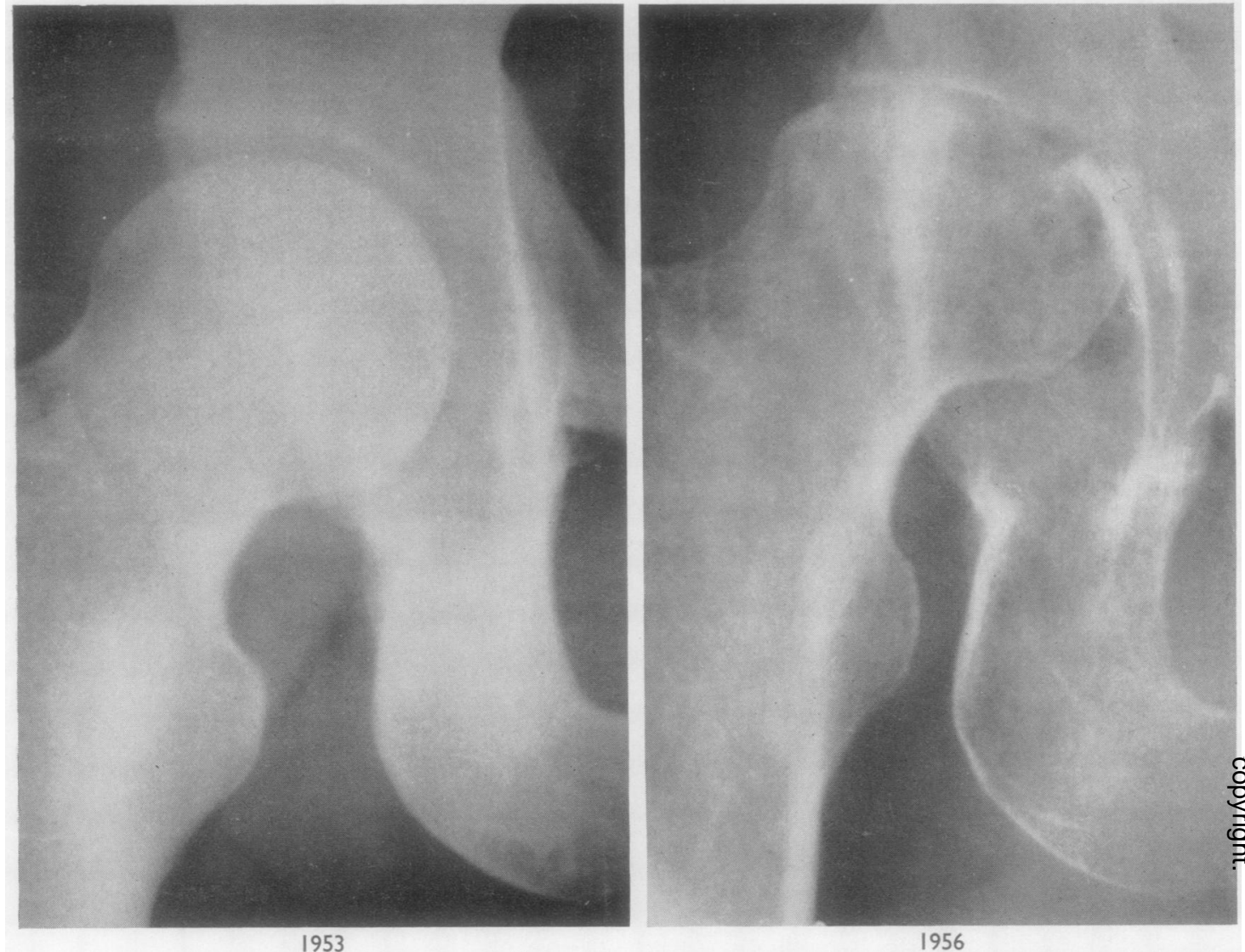

Fig. 4.-Case 2, right hip showing change between 1953 (left) and 1956 (right), with collapse, loss of cartilage, and formation of pseudo-cysts

between 1953 and 1957, and in the left hand fingers between 1953 and 1955. In 1953 they are normal; by 1955 erosion is seen beneath the radial articular edge; by 1957 this has progressed to leave a large "bite" out of the articular surface. Similar changes were seen in other digits of both hands.

The $x$ ray of the hip, which was normal in 1953 and in 1955 apart from an erosion of the pubic ramus, in 1956 showed some deformation, with collapse of the right femoral head but good preservation of the cartilage; by February, 1957, there was complete loss of cartilage and collapse of the femoral head (Fig. 4).

Comment.-The only symptoms from these marked bone changes occurred with collapse of the head of the right femur.

Case 3, a female aged 36 years, was admitted to hospital in November, 1946, with a story that in December, 1944, she had become weak, anorexic, and pruritic. At this time she was passing dark urine. One year later she became jaundiced. In 1946, at the Royal Devon Hospital, she was diagnosed as having biliary cirrhosis, the bile passages being normal radiologically and at operation.
Examination.-She was deeply jaundiced. There was a xanthomatous plaque on the right upper eyelid and dorsum of the right hand. The liver was enlarged three fingers breadth and the spleen was just palpable.

Laboratory Investigations.-Plasma bilirubin $7 \cdot 2 \mathrm{mg}$. per cent.; serum cholesterol $1,520 \mathrm{mg}$. per cent.; alkaline phosphatase 103 King Armstrong units.

Biopsy of the liver confirmed obstructive jaundice.

Progress.-In February, 1947, she complained of pain 3 in the elbows, fingers, and other bones; no joint lesions were found but there was extensive bone tenderness.

$X$ rays of the wrists and hands, skull, shoulders, femurs, and knees showed no abnormality, except small punctate areas of rarefaction in the proximal ends of both tibiae $N$ and right femur. Biopsy of the tibial cortex and under- lying marrow showed xanthoma cells and osteoclastic resorption of bone (Fig. 5, opposite).

She was transferred back to the care of Dr. Laird of the Royal Devon and Exeter Hospital. She died a year later of cerebral haemorrhage associated with hypoprothrombinaemia.

Comment.-It seems probable that the pain in this instance was due to bone change, although in the other 


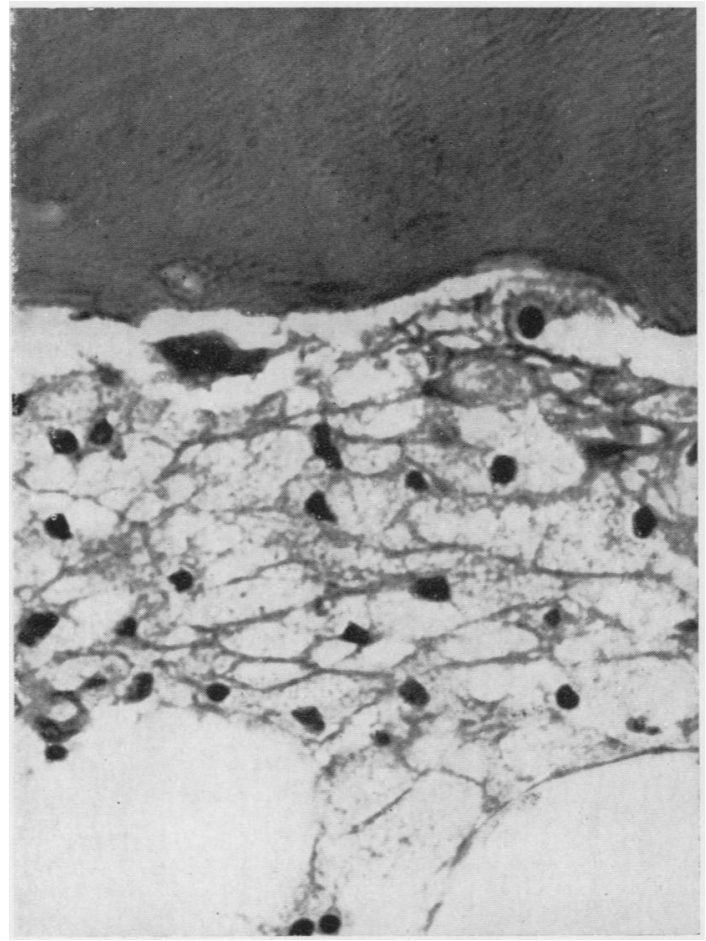

Fig. 5.-Case 3, biopsy of bone, showing foam cells and osteoclastic resorption of bone. Haematoxylin and eosin. $\times 508$.

two cases more advanced changes were symptomless.

In addition to these three patients the $x$ rays of the hands of two other patients suffering from biliary cirrhosis were reviewed, one being a woman of 28 years who had been ill for one year and whose cholesterol was now 1,140 mg. per cent., and the other a woman aged 54 years (Case 4), who had had symptoms for 3 years and whose cholesterol was $1,292 \mathrm{mg}$. per cent. In both cases osteoporosis alone was present.

Case 4, a 53-year old woman, had developed an acute angina of effort 10 days before admission to hospital. She had had severe retrosternal pain some 4 years previously, which had been treated with rest in bed, and had left no subsequent disability. In the 3 months before admission to hospital she had had some aching and swelling of the wrists and ankles.

Examination.-There were small xanthomatous nodules on the extensor tendons of the fourth right and third left metacarpophalangeal joints, and large nodules in both Achilles tendons about 3 in. above the heels. All the joints were normal.

The apex beat was displaced to the left and there was a systolic murmur at the apex and base. Blood pressure $180 / 100$.
Laboratory Investigations.-Erythrocyte sedimentation rate varying between 6 and $40 \mathrm{~mm}$./ hr (Westergren). C-reactive protein present; serum cholesterol $545 \mathrm{mg}$. per cent.; serum proteins: albumin $3.4 \mathrm{~g}$. per cent., globulin $3.7 \mathrm{~g}$. per cent.; fibrinogen $250 \mathrm{mg}$. per cent.; D.A.T. 1:2 (negative). Wassermann reaction and Kahn test negative.

Electrocardiogram showed changes suggestive of a recent myocardial infarction.

$X$ rays of the hands showed erosion of the paraarticular bone of the proximal phalanx of the third right finger producing a hook-like effect (Fig. 6) and some reticulation of the bone pattern.

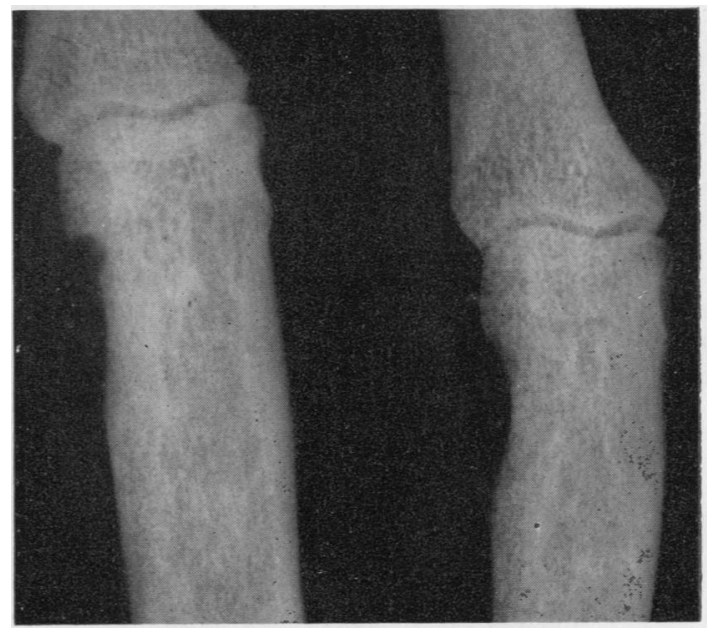

Fig. 6.-Case 4, $x$-ray of 3rd proximal phalanx, showing juxtaarticular erosion of bone. $\times 2$.

Diagnosis.-This patient was thought to be suffering from primary hypercholesterolaemia, with coronary occlusion, tendon deposits, and bone changes.

Three other cases of primary hypercholesterolaemia were also reviewed, but, although one has very extensive tendon deposits, the $x$ rays of the hands have shown no changes.

Case 5, a man aged 46, was first seen in 1941 at the age of 30 years, when he complained of pain and stiffness of the left hip for 5 years and recent pain in the back and shoulders. When he was aged 16 years his right leg had been amputated in the mid-thigh region for what was thought to be an osteomyelitis of 4 years' duration. When he was aged 22, after an injury to the left shin, the skin became brown and scaly. One year later he first developed pain in the left hip, associated with stiffness; this improved on physiotherapy, but a year later he developed pain in the right hip and now was found to have splenomegaly and a mild degree of anaemia. When he was 25 years old pain recurred in the left hip and was particularly troublesome on walking.

Examination.-He showed wedge-shaped pingueculae in the eyes, and pigmentation of the skin over the right 


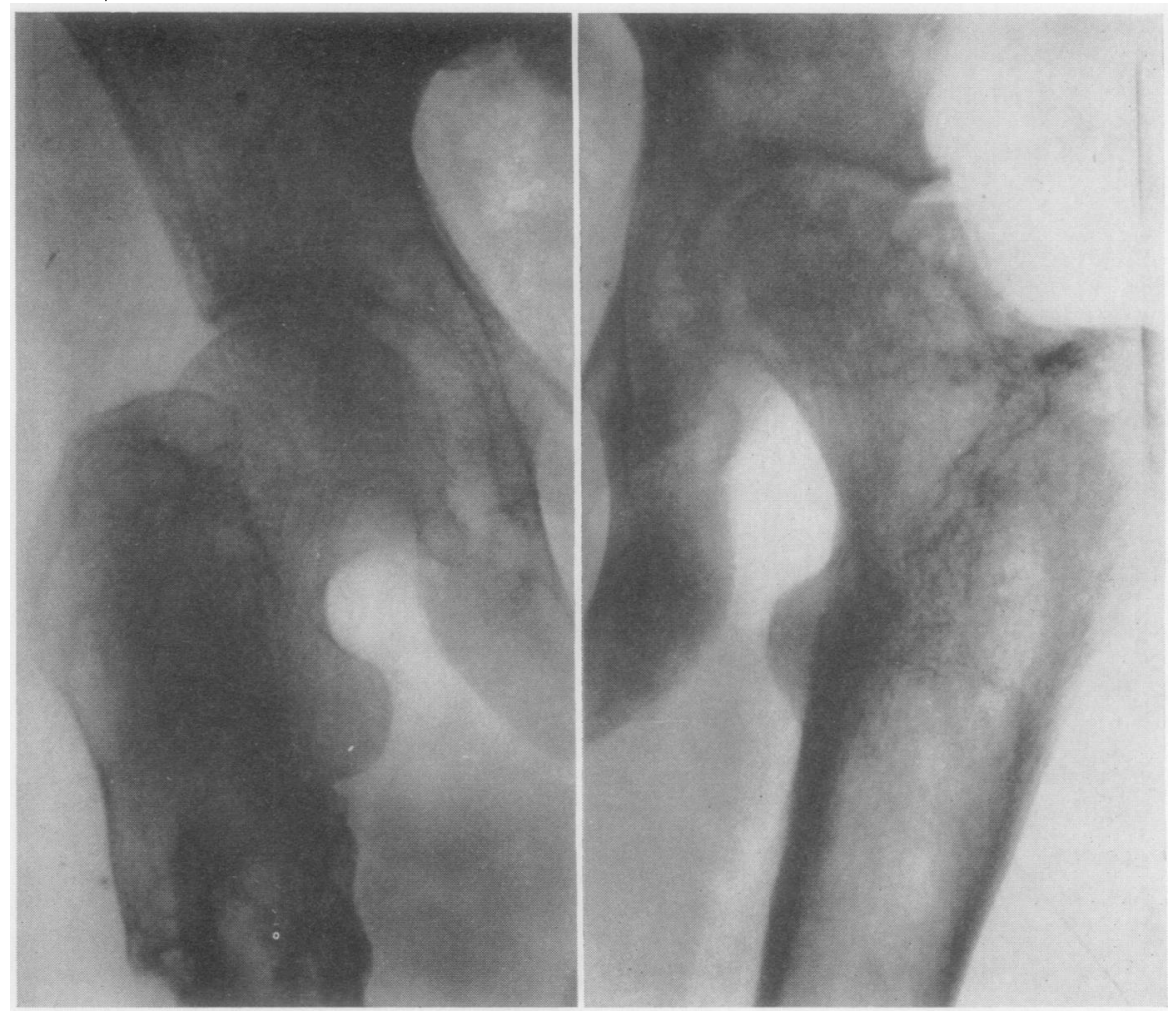

Fig. 7.-Case 5, hip joint in Gaucher's disease, showing collapse of left femoral head, with pseudo-cyst formation and secondary degenera tive changes.

inguinal ligament, right stump, and left leg; the spleen was moderately enlarged and the left hip showed marked limitation of all movements and was held in a position of flexion.

Laboratory Investigations.-Haemoglobin 68 per cent., white cell count $2,200 /$ c.mm., 70 per cent. polymorphs, platelets 200,000/cu.mm.; blood Wassermann reaction negative, sternal puncture showed Gaucher cells.

In $1936 x$ rays had shown rarefaction in the subtrochanteric and lower third of the shaft of the femur, and this was now more marked. Since that time he had continued to have pain and stiffness of the left hip.

Therapy.-A course of deep $x$-ray therapy in March, 1943, had no apparent effect and he continued to have increasing difficulty in walking any distance on that leg. $X$ rays of the hip showed widespread deposits and collapse of the femoral head which gradually became worse with secondary degenerative changes (Fig. 7).

Progress.-He has since had involvement of the right shoulder and more recently (1957) of the lumbar vertebrae.

Comment.-The collapse of the femoral head here seems to be of the same nature as that seen in Case 2 with biliary cirrhosis. It is of much longer standing, however, and secondary degenerative changes have occurred. The opposite hip, not weight-bearing, has not developed such changes.

\section{Discussion}

In contrast to the above categories of hyper? cholesterolaemic bone and joint lesions, the joint damage in reticulohistiocytosis recently reviewe $\overline{6}$ by Warin and others (1957) and by Johnson and Tilden (1957) may be much more severe, leading to arthritis mutilans or main-en-lorgnette (Warin an£ others, 1957; Johnson and Tilden, 1957) and apparently indistinguishable even in the earlief stages from rheumatoid arthritis. A few of hand $x$ rays have been published, but the reproduction is poor; no record of the earlier stage has been found apart from very minor changes illustrated by Caro and Senear (1952). We therefore reproduce, by pere mission of the authors, a hitherto unpublished $x$ rafe (Fig. 8, opposite) of the hands of the patient describ? ed by Graham and Stansfeld (1946). This could easily be mistaken for rheumatoid arthritis, but ther $\bar{\Phi}$ are some additional distinctive features visible even in this poor $x$ ray (see arrows), comprising para글 articular roughening, which is not seen if 


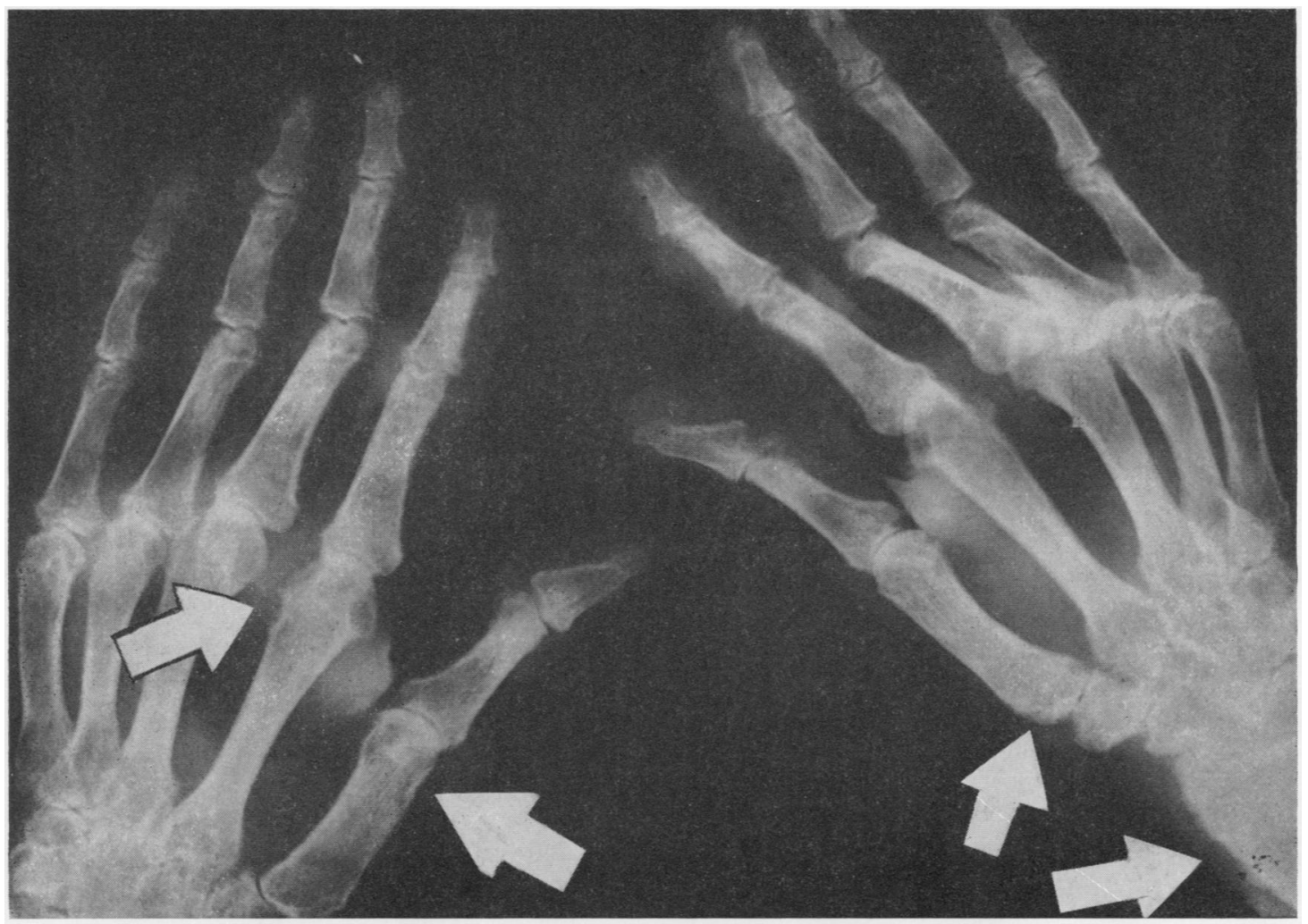

Fig. 8.- Case of Graham and Stansfeld (1946), $x$-ray of hands (hitherto unpublished) in reticulohistiocytosis, showing rheumatoidlike joint changes, with loss of cartilage, subchondral erosions, and (arrows) bone erosion at typical juxta-articular areas.

rheumatoid arthritis alone. The pathological description includes "patchy erosion" of bone "on the deep surface of the periosteum" as well as hyperplastic granulation tissue containing foam cells, covering and eroding articular cartilage (well illustrated). These features are very similar to those pictured in the excellent hand $x$ ray reproductions of hypercholesterolaemia published by Gaál (1933) and Merrill (1920).

Although we have no pathological data on the joints in biliary cirrhosis, a somewhat similar pathological process could be envisaged therein, producing the effects described above. It seems to us that the joint lesion in hypercholesterolaemia is likely to be an infiltration of subchondral and subperiosteal bone by foam cells, with mechanical damage at areas of stress due to weakening and collapse of bone. This theory is supported by the collapse of the femoral head, so similar to that found and recorded in Gaucher's disease (VaughanJackson, 1952).
These various types of infiltrating histiocytes have the common action of displacing and weakening bone; the lesions they produce, although varying according to the type and distribution of metabolic upset present, have many features in common and represent another "metabolic" disease of joints, with ordinary mechanical microtraumata as a probable precipitating factor.

\section{Summary}

Three cases of biliary cirrhosis with hypercholesterolaemia and bone lesions are described. In two, lesions of the subchondral bone led to articular lesions, symptomless except when collapse of the femoral head produced hip pain and secondary osteo-arthritis. The lesions are compared with those found in idiopathic hypercholesterolaemia, Gaucher's disease, and reticulohistiocytosis, and it is concluded that mechanical weakening and replacement of subchondral bone by foam cells is an important factor. 
We wish to thank our colleagues at the Postgraduate Medical School, and particularly Dr. Sheila Sherlock who kindly referred the cases of biliary cirrhosis and allowed us to use the data on them. Dr. Graham and Dr. Stansfeld kindly allowed us to reproduce Fig. 8.

\section{REFERENCES}

Corazza, L. J., and Myerson, R. M. (1957). Amer. J. Med., 22, 258. Caro, M. R., and Senear, F. E. (1952). A.M.A. Arch. Derm. Syph., 65,701 .

Fletcher, E. (1946). Annals of the Rheumatic Diseases, 5, 88.

Gaál, A. (1933). Fortsch. Röntgenstr., 48, 292.

Golden, G. N., and Richards, H. G. H. (1953). J. Bone Jt Surg., 35-B, 275.

Graham, G., and Stansfeld, A. G. (1946). J. Path. Bact., 58, 545.

Harslöf, E. (1948). Acta med. scand., 130, 140.

Hopgood, W. C. (1948). New Engl. J. Med., 238, 429. Johnson, H. M., and Tilden, I. L. (1957). A.M.A. Arch. Derm.,

Layani, F. (1939). Bull. Soc. méd. Hôp. Paris, 55, 343.

Lever, W. F., Smith, P. A. J., and Hurley, N. A. (1954). J. invest. Derm., 22, 33.

MacMahon, H. E. (1948). Amer. J. Path., 24, 527.

March, H. C., Gilbert, P. D., and Kain, T. M. (1957). Amer. J. Roentgenol., 77, 109.

Merrill, A. S. (1920). Ibid., 7, 480

Movitt, E. R. (1956). Ann. intern. Med., 45, 242.

Vaughan-Jackson, O. J. (1952). J. Bone Jt Surg., 34-B, 460.

Vishnevsky, J. (1939). "Etude d'une forme nouvelle de rhumatisme chronique déformant xanthomateux." Le François, Paris.

Warin, R. P., Evans, C. D., Hewitt, M., Taylor, A. L., Price, C. H. G., and Middlemiss, J. H. (1957). Brit. med. J., 1, 1387.

\section{Maladie histiocytique de l'os et de l'articulation}

RÉSUMÉ

On décrit trois cas de cirrhose biliaire avec hyper-? cholestérolémie et lésions osseuses. Dans deux cas, deslésions de l'os subchondrial menèrent à des lésionses? articulaires, asymptomatiques, sauf quand l'affaissemento de la tête fémorale produisit des douleurs dans la hanchê et une ostéo-arthrite secondaire. On compare ces lesions avec celles constatées dans l'hypercholestérolémieidiopathique, la maladie de Gaucher et la réticulo $\mathbb{Q}$ histiocytose et on conclut que l'affaiblissement mécaniquen et le remplacement de l'os subchondrial par des cellules "spumeuses"( foam cells) sont des facteurs importants.

Enfermedad histiocítica del hueso y de la articulación SUMARIO

Se describen tres casos de cirrosis biliar con hiper colesterolemia y lesiones óseas. En dos casos, lesiones del hueso subchondrial llevaron a lesiones articulares $\vec{\sigma}$ sin síntomas, excepto cuando el colapso de la cabezás femoral produjo dolores en la cadera y una ósteoartritisi secundaria. Se comparan estas lesiones con las enconw tradas en la hipercolesterolemia idiopática, la enfermedab de Gaucher y la retículohistiocitosis y se concluye que el debilitamiento mecánico y la sustitución del hues $\sigma$ subchondrial por células "espumosas" (foam cells constituyen factores importantes. 